\title{
Relationship Between SUVmax and ADC Values of Metastatic Lymph Nodes Detected by Ga-68 PSMA PET/MR in Prostate Cancer Patients
}

\author{
Prostat Kanseri Hastalarında Ga-68 PET/MR ile Saptanan Metastatik \\ Lenf Nodlarına Ait SUVmaks ve ADC Değerleri Arasındaki İlişki
}

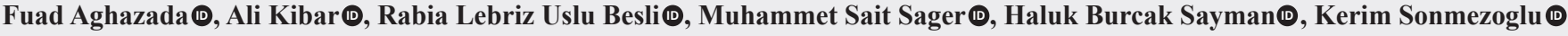

Department of Nuclear Medicine, Istanbul University-Cerrahpaşa, Cerrahpaşa Medical Faculty, Istanbul, Turkey

Cite as: Aghazada F, Kibar A, Uslu-Besli RL, Sager MS, Sayman HB, Sonmezoglu K. Relationship between SUVmax and ADC values of metastatic lymph nodes detected by Ga-68 PSMA PET/MR in prostate cancer patients. Grand J Urol 2022;2(1):15-20.

Submission date: 31 August 2021

Acceptance date: 29 November 2021

Online First: 06 December 2021

Publication date: 20 January 2022

Corresponding Author: Fuad Aghazada / Istanbul University-Cerrahpaşa, Cerrahpaşa Medical Faculty, Department of Nuclear Medicine, Istanbul, Turkey / fuad.aghazada@gmail.com / ORCID ID: 0000-0001-9519-3455

\begin{abstract}
Objective: Our aim is to assess if there is a relationship between maximum standardized uptake (SUVmax) and apparent diffusion coefficient (ADC) values of reactive and metastatic lymph nodes, also to compare ADC values of reactive and metastatic lymph nodes in prostate cancer patients.

Materials and Methods: We have retrospectively investigated 20 patients diagnosed with prostate cancer who underwent Ga-68 PSMA PET/MR imaging. Three metastatic and three reactive lymph nodes classified according to PSMA Ga-68 uptake in PET/MR were chosen for each patient. SUVmax and ADCmean values were calculated for each lymph node separately. SPSS version 22 was used for statistical analysis.

Results: A total of 120 lymph nodes in 20 prostate cancer patients were assessed. There was a weak negative correlation between SUVmax values and $\mathrm{ADCmean}$ values of metastatic lymph nodes $(\mathrm{p}=0.009, \mathrm{r}=-0.333)$. However, there was no significant correlation between SUVmax values and ADCmean values of reactive lymph nodes $(\mathrm{p}=0,271, \mathrm{r}=-0,144)$. ADCmean values of metastatic lymph nodes were significantly lower than those of reactive lymph nodes $(\mathrm{p}=0.0001)$.

Conclusion: PET/MR, which combines both advantages of PET and MRI, is an important tool for the diagnosis and management of prostate cancer. We have found that SUVmax values of metastatic lymph nodes were inversely correlated with ADCmean values and combination of both parameters may increase the diagnostic accuracy of Ga-68 PSMA PET/MR in the detection of lymph node metastasis.
\end{abstract}

Keywords: prostate cancer, lymph node metastasis, Ga-68 PSMA, positron emission tomography

Öz

Amaç: Amacımız, prostat kanserli hastalarda reaktif ve metastatik lenf nodlarının maksimum standardize uptake değeri (SUVmaks) ile görünür difüzyon katsayısı (ADC) değerleri arasında bir ilişki olup olmadığını değerlendirmek, ayrıca reaktif ve metastatik lenf nodlarının ADC değerlerini karşılaştırmaktır. Gereçler ve Yöntemler: Ga-68 PSMA PET/MR görüntüleme yapılmış prostat kanseri tanılı 20 hastanın görüntüleri retrospektif olarak incelendi. Her hasta için PSMA PET tutulumuna göre sınıflandırılan üç metastatik ve üç reaktif lenf nodu seçildi. SUVmax ve ADCortalama değerleri her bir lenf nodu için ayrı ayrı hesaplandı. İstatistiksel analiz için SPSS versiyon 22 kullanıldı.

Bulgular: Yirmi prostat kanserli hastada toplam 120 lenf nodu değerlendirildi. SUVmaks değerleri ile metastatik lenf nodu ADCortalama değerleri arasında düşük düzeyde negatif korelasyon vardı $(\mathrm{p}=0,009, \mathrm{r}=-0,333)$. Ancak SUVmaks değerleri ile reaktif lenf nodlarının ADCortalama değerleri arasında anlamlı bir ilişki yoktu ( $\mathrm{p}=0,271, \mathrm{r}=-0,144)$. Metastatik lenf nodlarının ADCortalama değerleri, reaktif lenf nodlarından anlamlı derecede düşüktü ( $\mathrm{p}=0,0001)$.

Sonuç: PET ve MR'ın avantajlarını bir araya getiren PET/MR, prostat kanseri teşhisi ve tedavisi için önemli bir araçtır. Metastatik lenf nodlarının SUVmaks değerlerinin ADCortalama değerleri ile ters orantılı olduğunu ve her iki parametrenin kombinasyonunun lenf nodu metastazının saptanmasında Ga-68 PSMA PET/MR'ın tanısal doğruluğunu artırabileceğini bulduk.

Anahtar kelimeler: prostat kanseri, lenf nodu metastazı, Ga-68 PSMA, positron emisyon tomografisi

\footnotetext{
ORCID ID: A. Kibar 


\section{Introduction}

According to American Cancer Society, prostate cancer is the second most common cancer among men after skin cancer and also the second most common cause of cancer related mortality among men. Early detection and treatment is crucial. Prostate specific membrane antigen (PSMA) is a type 2 integral membrane protein which is shown to be overexpressed in prostate cancer cells $[1,2]$. Expression of PSMA increases with the grade of cellular dysplasia [3]. As the grade of prostate cancer increases PSMA expression also increases [4]. For imaging and therapeutic use, PSMA is radiolabeled with different radionuclides and to date Gallium-68 labeled PSMA (Ga-68 PSMA) is the most commonly used PSMA-targeted radiopharmaceutical for imaging.

Standardized uptake value (SUV) is a measure which shows uptake level in PET scan. Higher SUV values mean higher radiotracer uptake within that lesion. Apparent diffusion coefficient (ADC) is a measure of the diffusion of water molecules within tissue which is calculated for magnetic resonance imaging (MRI) lesions. Ga-68 PSMA positron emission tomography (PET) is a useful tool for the staging and follow-up of the primary disease as it shows increased uptake in PSMA- positive lesions of prostate cancer [5]. The development of integrated positron emission tomography/magnetic resonance imaging (PET/MR) devices enables simultaneous acquisition of PET and MRI, which increases the accuracy of PET imaging in prostatic as well as other soft tissue lesions [6]. Prostate cancer frequently metastasizes to regional lymph nodes and Ga-68 PSMA PET is a highly sensitive and specific imaging modality for the detection of metastatic lymph nodes [7]. Patients with higher Gleason scores show higher radiotracer uptake [8]. Maximum SUV (SUVmax) of primary prostate lesions acquired by Ga-68 PSMA PET have been shown to have positive correlation with Gleason scores [9]. Conversely, ADC values of prostate lesions, acquired from MRI images have been negatively correlated with Gleason scores [10]. Also, an inverse correlation between SUVmax and ADCmean of primary prostate lesions have been recorded and the prognostic importance of both of them for the detection of the status of lymph node metastases has been shown [11]. Similar to prostate lesions, ADC values of metastatic lymph nodes are expected to be lower than those of reactive lymph nodes [12]. In this study, we have aimed to evaluate the ADC values of metastatic and reactive lymph nodes in prostate cancer patients and to assess the relationship between ADC and PSMA SUV values, if any.

\section{Materials and Methods \\ Study Population}

This study was approved by the institutional Clinical Research Ethics Committee of Cerrahpasa Medical Faculty (2019/6927). Our study was conducted between 02/2017, and 04/2018. Twenty patients diagnosed with prostate cancer who underwent Ga-68 PSMA PET/MRI imaging were retrospectively included in our analysis. Mean age of the patients was 68,2 7,4 (range: 58-82 years). All patients had verified prostate biopsy results. Gleason scores of patients are given in Table 1. Patients with prostate cancer diagnosis, who underwent PSMA PET imaging, and had more than three metastatic and reactive lymph nodes were included in our study. Prostate cancer patients having less than three metastatic/ reactive lymph nodes were not enrolled in the study.

\section{Imaging}

Patients were imaged after intravenous injection of mean activity of $6,3 \pm 1,73 \mathrm{mCi}$ Ga-68 PSMA HBED-CC. Radiolabeling procedure was performed using a fully automated radiopharmaceutical synthesis device (Eckert \& Ziegler Eurotope, Berlin, Germany). All PET/MRI images were acquired using an integrated 3 Tesla- PET/MRI scanner (GE Signa PET/MRI, GE Healthcare, Waukesha, Wisconsin, USA). Patients underwent whole body PET/MRI imaging at an average of $67,16 \pm 18,8$ minutes after injection. Sequences obtained by PET/MRI consisted of an initial localizer scan, a 3D dual-echo fast spoiled gradient recalled echo liver-accelerated volume acquisition sequence (LAVAFLEX) for MRI based attenuation correction (MRAC), followed by a high-resolution axial T1-weighted (T1W) 3D LAVA-FLEX sequence, diffusion-weighted imaging (DWI) with b values: 50 and $1000 \mathrm{~s} / \mathrm{mm} 2$ and corresponding ADC mapping.

\section{Image Analysis}

Ga-68 PSMA PET/MRI images of 20 patients were retrospectively reviewed and analyzed using GE AW Volume Share 7 workstation (GE Medical Systems, Buc, France). Three metastatic and three reactive lymph nodes were chosen for each patient according to PSMA PET findings. Lymph nodes which showed markedly increased Ga-68 PSMA uptake compared to background activity were considered as metastatic (Figure 1). Inguinal lymph nodes without significant PSMA uptake or any morphological appearance suspicious for metastasis (including

Table 1. Gleason scores and PSA values of the patients

\begin{tabular}{l|l}
\hline Gleason score & Number of patients (median PSA values $\mathbf{n g} / \mathbf{m l})$ \\
\hline $3+3$ & $1(628.0)$ \\
\hline $3+4$ & $4(42.0 ;$ range: $0.2-81.4)$ \\
\hline $4+3$ & $5(13.2 ;$ range: $1.1-21.6)$ \\
\hline $4+4$ & $3(22.2 ;$ range: $8.5-84.3)$ \\
\hline $4+5$ & $3(119.3 ;$ range: $52.1-155.2)$ \\
\hline $5+4$ & $3(207.1 ;$ range: $58.3-934.4)$ \\
\hline $5+5$ & $1(18.8)$ \\
\hline
\end{tabular}

PSA: prostate specific antigen 

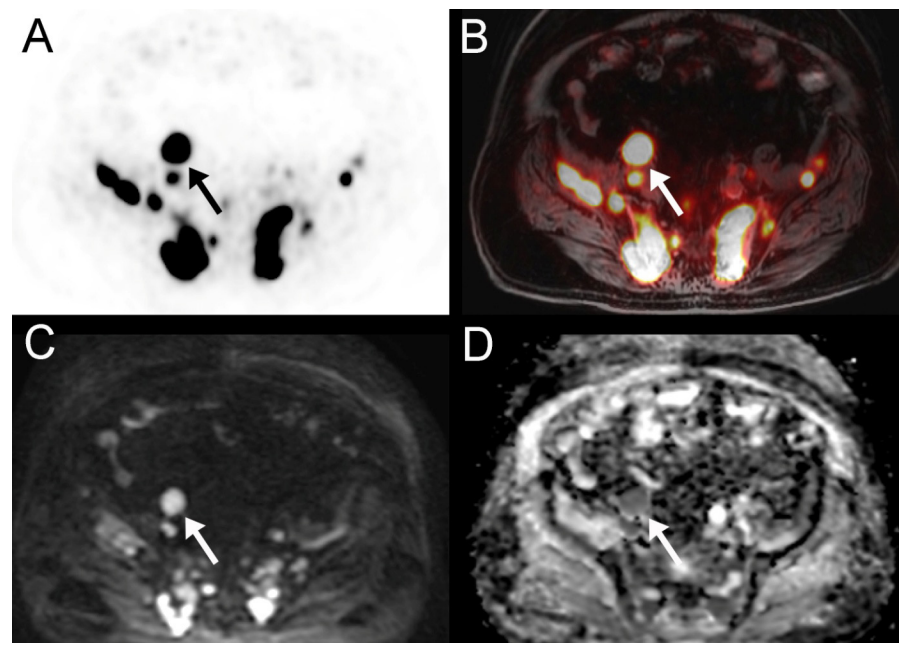

Figure 1. A 79-year-old patient with Gleason score $5+5$ prostate cancer. Metastatic common iliac lymph node is shown with arrow (SUVmax $37,5 \mathrm{gr} / \mathrm{ml}$; ADCmean 0,000812 $\left.\mathrm{mm}^{2} / \mathrm{s}\right)$. A: PET image; B: PET/MR fusion; C: DWI (b:1000); D: ADC

abnormal size, shape and cortical thickness) were regarded as reactive lymph nodes (Figure 2). SUVmax and ADCmean values were calculated for each lymph node separately by drawing a region of interest (ROI) within each lymph node.

\section{Statistical Analysis}

SPSS software version 22 (IBM Corp., Armonk, New York, USA) was used for statistical analysis. $\mathrm{P}<0.05$ was accepted as the level of statistical significance. Normal distribution of the values in the population was confirmed by both the KolmogorovSmirnov test and the histogram curves. Linear regression analysis was performed to determine the relationship between SUVmax and ADCmean values, and Spearman correlation analysis to determine the significance of this relationship. Student T-test was performed to analyze the relationship between ADC values. ROC analysis for $\mathrm{ADC}$ values was also made.

\section{Results}

A total of 120 lymph nodes in 20 prostate cancer patients with Gleason scores of $3+3(n=1), 3+4(n=4), 4+3(n=5), 4+4(n=3)$, $4+5(n=3), 5+4(n=3)$, and $5+5(n=1)$ were assessed (Table 1). SUVmax and ADCmean values of the lymph nodes are given in Table 2. SUVmax values of metastatic and reactive lymph nodes were between 5.57-62.53 and 0.20-2.51, respectively. Mean $( \pm$ SD) SUVmax and SUVmean values for metastatic lymph nodes were $19.17( \pm 13.60)$ and $12.63( \pm 7.78)$, respectively. Mean $( \pm$ $\mathrm{SD}) \mathrm{ADC}$ values for metastatic and reactive lymph nodes were $9.78( \pm 2.71)$ and $13.3( \pm 4.52)$, respectively (Figure 3).

ADCmean values of metastatic lymph nodes were significantly lower than those of reactive lymph nodes $(p=0.0001)$. Cut- off value for $\mathrm{ADC}$ was calculated as 0,001595 (sensitivity: $30 \%$, specificity: 98\%). There was a weak negative correlation between SUVmax values and ADCmean values of metastatic lymph nodes $(\mathrm{p}=0.009, \mathrm{r}=-0.3)$ (Figure 4a). However, there was no significant correlation between SUVmax values and ADCmean values of reactive lymph nodes $(\mathrm{p}=0.271, \mathrm{r}=-0.2)$ (Figure $\mathbf{4 b}$ ).
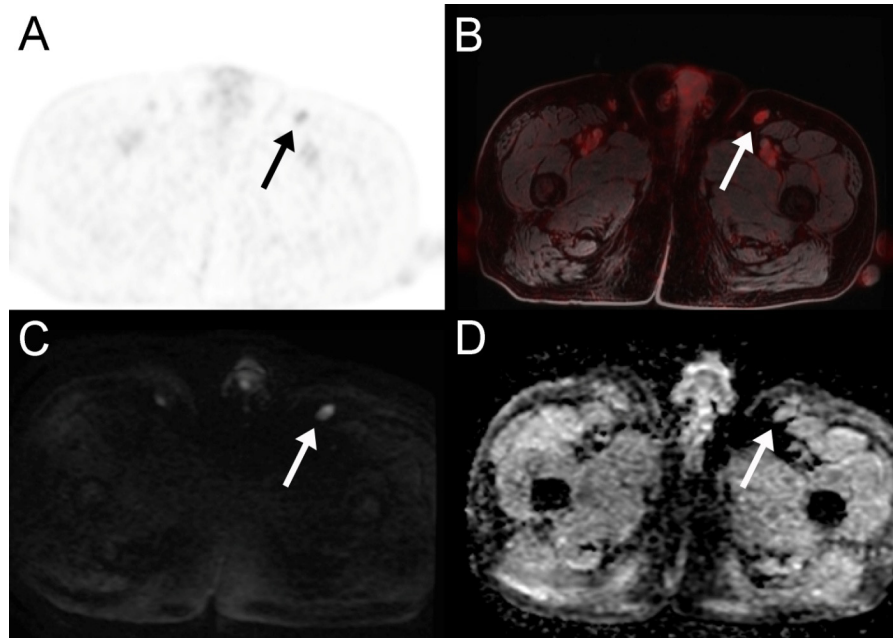

Figure 2. A 53-year-old patient with Gleason score 4+3 prostate cancer. Lower SUVmax and higher ADCmean values for reactive left inguinal lymph node is shown with arrow (SUVmax 2,51 gr/ml; ADCmean 0,00170 $\mathrm{mm} 2 / \mathrm{s})$. A: PET image; B: PET/MR fusion; C: DWI (b:1000); D: ADC

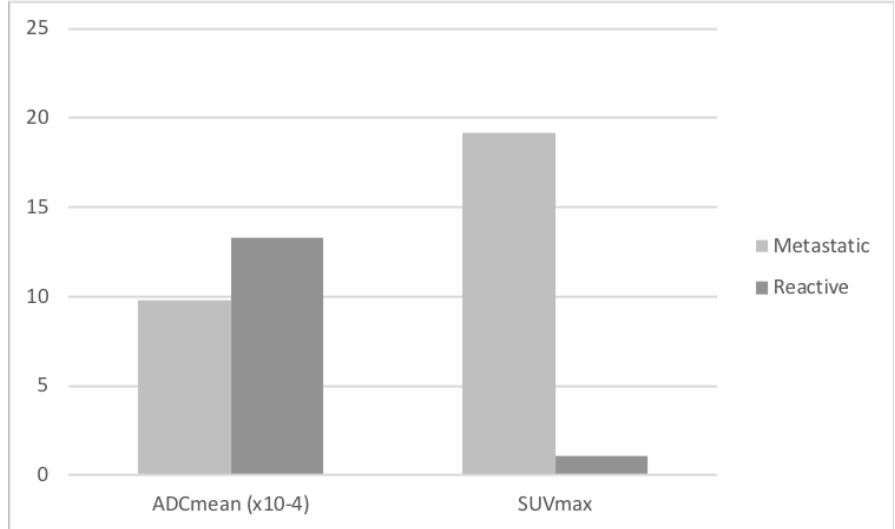

Figure 3. Comparison of ADCmean and SUVmax values of metastatic and reactive lymph nodes. Metastatic lymph nodes have lower ADCmean values and higher SUVmax values

\section{Discussion}

PSMA PET is a relatively new diagnostic imaging tool for the detection of prostate cancer, however its demand for it increases rapidly. It shows higher radiotracer uptake in patients with higher Gleason scores [8], and also higher diagnostic sensitivity and specificity for lymph node metastasis [13]. PSMA PET changes prostate cancer management decisions for many patients [14, 15].

DWI is based upon the random Brownian motion of water molecules within the tissue and gives microstructural information about the tumor tissue. Normal or reactive lymph nodes also show a relatively restricted diffusion due to high cellular density. However, metastatic lymph nodes have higher cellular density, which further restricts diffusion compared to normal or reactive lymph nodes [16]. The resulting signal changes in restricted diffusion in MRI are high-signal intensity on DWI with corresponding reduced apparent diffusion coefficient (ADC) values. In our study we found lower ADC values in metastatic lymph nodes compared to reactive lymph nodes consistent with the current literature data.

Ga-68 PSMA PET targets PSMA, which is a membrane 

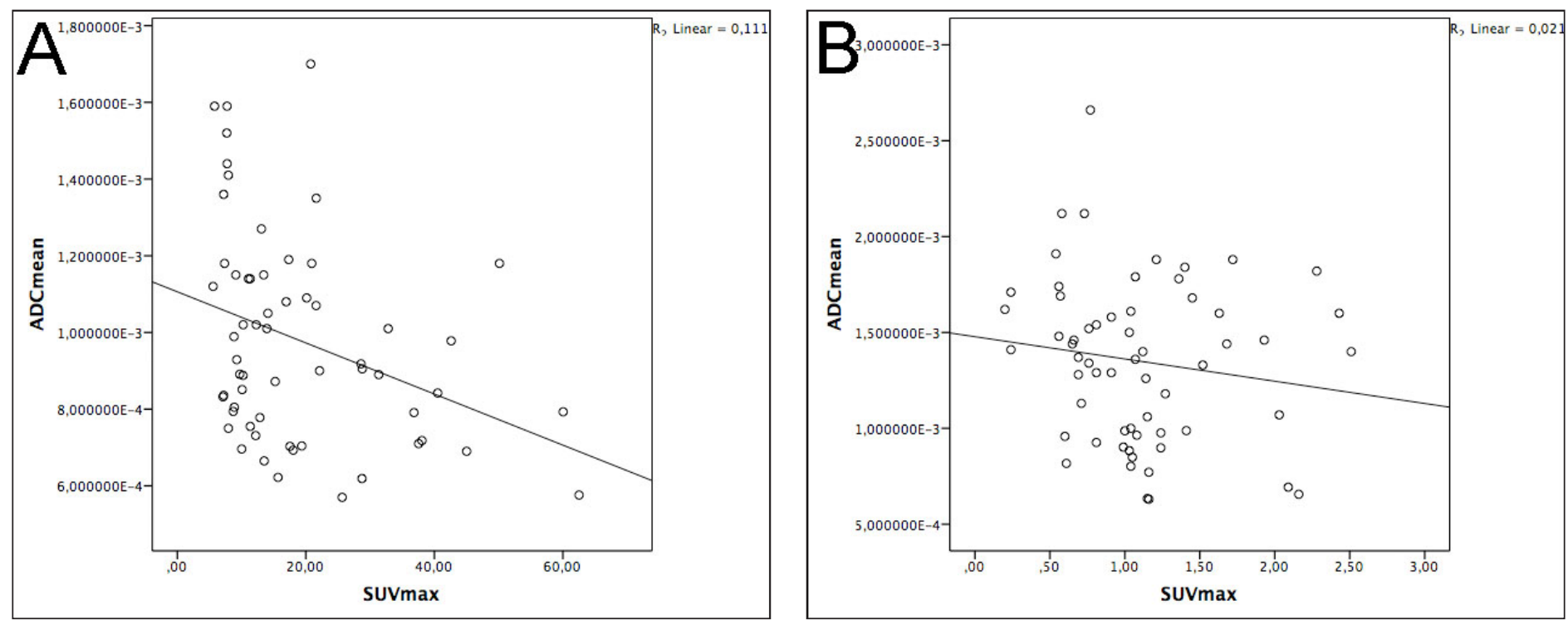

Figure 4. Correlation of ADCmean and SUVmax values. Metastatic lymph nodes have weak inverse correlation (A), whereas reactive lymph nodes do not have significant correlation (B)

Table 2. SUV and ADC values of lymph nodes

\begin{tabular}{l|l|l}
\hline & Mean \pm Standard deviation & Range \\
\hline Metastatic lymph nodes & & \\
\hline SUVmax $(\mathrm{g} / \mathrm{ml})$ & $19.17 \pm 13.60$ & $5.57-62.53$ \\
\hline SUVmean $(\mathrm{g} / \mathrm{ml})$ & $12.63 \pm 7.78$ & $4.17-41.65$ \\
\hline ADCmean $\left(\mathrm{x} 10^{-4}\right)\left(\mathrm{mm}^{2} / \mathrm{s}\right)$ & $9.78 \pm 2.71$ & $5.70-17.0$ \\
\hline Reactive lymph nodes & & \\
\hline SUVmax $(\mathrm{g} / \mathrm{ml})$ & $1.10 \pm 0.53$ & $0.20-2.51$ \\
\hline SUVmean $(\mathrm{g} / \mathrm{ml})$ & $0.79 \pm 0.32$ & $0.11-1.49$ \\
\hline ADCmean $\left(\mathrm{x} 10^{-4}\right)\left(\mathrm{mm}^{2} / \mathrm{s}\right)$ & $13.30 \pm 4.52$ & $1.29-26.60$ \\
\hline
\end{tabular}

SUVmax: maximum standardized uptake value; SUVmean: mean standardized uptake value; ADCmean: mean apparent diffusion coefficient

protein expressed 100-1000-fold higher in prostate cancer cells than in normal tissues and provides metabolic information about prostate cancer cells [17]. SUV is a semi-quantitative parameter reflecting PSMA uptake of tissues. PSMA PET was shown to have positive correlation with Gleason scores [18]. Also, ADC values were shown to be inversely correlated with Gleason scores [19]. We found a weak inverse correlation between SUVmax values and ADCmean values in metastatic lymph nodes. Inverse correlation was also reported previously for bone lesions and primary prostate lesions in prostate cancer $[20,21]$. Wetter et al found moderately significant inverse correlation between SUVmax and ADC values of metastatic bone lesions of prostate cancer [22]. Also, Uslu-Besli et al found an inverse relationship between SUVmax and ADC values of primary prostate lesions detected by PSMA PET/MRI [11]. Wang et al showed that ADC values had significant negative correlation with Gleason score and SUVmax in primary prostate lesions [23]. Wu et al found that minimum ADC values inversely correlated with the Gleason score in prostate lesions [24].

Most scientific articles compared SUVmax values obtained by PET/CT with MRI ADC values, however in our study we used hybrid PET/MR machine for determining SUVmax and ADC values. Contrary to sequential PET/CT imaging, hybrid PET/MR involves simultaneous acquisition of PET and MRI images which enables excellent PET and MRI fusion, reducing the fusionrelated artifacts. Also, as MRI has better soft-tissue resolution compared to CT, detection and characterization of lymph nodes is better with PET/MR compared to PET/CT.

The main limitation of our study is its small sample size. We have evaluated 120 lymph nodes in 20 patients. Lack of histopathological diagnosis of lymph nodes is another limitation of our study.

\section{Conclusion}

PET/MR, which combines both advantages of PET and MRI, is an important tool for prostate cancer diagnosis and management. ADCmean values of metastatic lymph nodes were found to be significantly lower than those of reactive lymph nodes. Also, SUVmax values and ADCmean values of metastatic lymph nodes were found to be inversely correlated. Combination of both SUVmax values and ADCmean values may reinforce each other 
and increase the diagnostic accuracy of Ga-68 PSMA PET/MR in the detection of lymph node metastases.

Ethics Committee Approval: This study was approved by Cerrahpaşa Medical Faculty Clinical Research Ethics Committee (Approval number, and registration number: 01/14/2019-6927).

Informed Consent: An informed consent was obtained from all the patients.

Publication: The results of the study were not published in full or in part in form of abstracts.

Peer-review: Externally and internally peer-reviewed.

Authorship Contributions: Any contribution was not made by any individual not listed as an author. Concept - F.A., A.K., R.L.U.B.; Design - F.A., A.K., R.L.U.B.; Supervision - F.A., K.S.; Resources - M.S.S., H.B.S.; Materials - M.S.S., H.B.S.; Data Collection and/or Processing - R.L.U.B., M.S.S., H.B.S.; Analysis and/or Interpretation - F.A., R.L.U.B., K.S.; Literature Search - M.S.S., H.B.S.; Writing Manuscript - F.A., A.K., R.L.U.B.; Critical Review - F.A., K.S.

Conflict of Interest: The authors declare that they have no conflict of interest.

Financial Disclosure: The authors declare that this study received no financial support.

\section{References}

[1] Chang SS. Overview of prostate-specific membrane antigen. Rev Urol 2004;6:13-8.

https://pubmed.ncbi.nlm.nih.gov/16985927/.

[2] Wester HJ, Schottelius M. PSMA-Targeted radiopharmaceuticals for imaging and therapy. Semin Nucl Med 2019;49:302-12.

https://doi.org/10.1053/j.semnuclmed.2019.02.008.

[3] Bostwick DG, Pacelli A, Blute M, Roche P, Murphy GP. Prostate specific membrane antigen expression in prostatic intraepithelial neoplasia and adenocarcinoma: a study of 184 cases. Cancer 1998;82:2256-61.

https://doi.org/10.1002/(sici)1097-0142(19980601)82:11<2256::aidcncr22>3.0.co;2-s.

[4] Bravaccini S, Puccetti M, Bocchini M, Ravaioli S, Celli M, Scarpi E, et al. PSMA expression: a potential ally for the pathologist in prostate cancer diagnosis. Sci Rep 2018;8:4254.

https://doi.org/10.1038/s41598-018-22594-1.

[5] Perera M, Papa N, Christidis D, Wetherell D, Hofman M S, Murphy D G, et al. Sensitivity, specificity, and predictors of positive Ga-68-prostate-specific membrane antigen positron emission tomography in advanced prostate cancer: a systematic review and meta-analysis. Eur Urol 2016;70:926-37.

https://doi.org/10.1016/j.eururo.2016.06.021.

[6] Eiber, M, Weirich, G, Holzapfel, K., Souvatzoglou, M., Haller, B, Rauscher I, et al. Simultaneous 68Ga-PSMA HBED-CC PET/MRI Improves the Localization of Primary Prostate Cancer. Euro Urol 2016;70:829-36.

https://doi.org/10.1016/j.eururo.2015.12.053.
[7] Bernstein AN, Shoag JE, Golan R, Halpern JA, Schaeffer EM, Hsu, WC. et al. Contemporary Incidence and Outcomes of Prostate Cancer Lymph Node Metastases. J Urol 2018;199:1510-7. https://doi.org/10.1016/j.juro.2017.12.048.

[8] Chen M, Qiu X, Zhang Q, Zhang C, Zhou Y, Zhao X, et al. PSMA uptake on [68Ga]-PSMA-11-PET/CT positively corrects with prostate cancer aggressiveness. Q J Nucl Med Mol Imaging 2019; Suppl.

https://doi.org/10.23736/S1824-4785.19.03172-8.

[9] Uprimny C, Kroiss AS, Decristoforo C, Fritz J, von Guggenberg E, Kendler D, et al. 68Ga-PSMA-11 PET/CT in primary staging of prostate cancer: PSA and Gleason score predict the intensity of tracer accumulation in the primary tumour. Eur J Nucl Med Mol Imaging 2017;44;941-9. https://doi.org/10.1007/s00259-017-3631-6.

[10] Surov A, Meyer HJ, Wienke A. Correlations between apparent diffusion coefficient and Gleason score in prostate cancer: A Systematic Review. Eur Urol Oncol 2020;3:48997.

https://doi.org/10.1016/j.euo.2018.12.006.

[11] Uslu-Beşli L, Bakır B, Asa S, Güner E, Demirdağ Ç, Şahin OE, et al. Correlation of SUVmax and apparent diffusion coefficient values detected by Ga-68 PSMA PET/MRI in primary prostate lesions and their significance in lymph node metastasis: Preliminary results of an on-going study. Mol Imaging Radionucl Ther. 2019;28:104-11. https://doi.org/10.4274/mirt.galenos.2019.63825.

[12] Vag T, Heck MM, Beer AJ, Souvatzoglou M, Weirich G, Holzapfel K, et al. Preoperative lymph node staging in patients with primary prostate cancer: comparison and correlation of quantitative imaging parameters in diffusionweighted imaging and 11C-choline PET/CT. Eur Radiol 2014;24:1821-6. https://doi.org/10.1007/s00330-014-3240-8.

[13] Maurer T, Gschwend JE, Rauscher I, Souvatzoglou M, Haller B, Weirich G, et al. Diagnostic efficacy of (68) Gallium-PSMA positron emission tomography compared to conventional 'maging for lymph node staging of 130 consecutive patients with intermediate to high risk prostate cancer. J Urol 2016;195:1436-43.

https://doi.org/10.1016/j.juro.2015.12.025.

[14] Hope TA, Aggarwal R, Chee B, Tao D, Greene KL, Cooperberg MR, et al. Impact of 68Ga-PSMA-11 PET on management in patients with biochemically recurrent prostate cancer. J Nucl Med 2017;58:1956-61. https://doi.org/10.2967/jnumed.117.192476.

[15] Han S, Woo S, Kim YJ, Suh CH. Impact of 68Ga-PSMA PET on the Management of patients with prostate cancer: A Systematic Review and Meta-analysis. Eur Urol 2018;74:179-90.

https://doi.org/10.1016/j.eururo.2018.03.030.

[16] Abdel Razek AAK, Soliman NY, Elkhamary S, Alsharaway MK, Tawfik A. Role of diffusion-weighted MR imaging in cervical lymphadenopathy. Euro Radiol 2006;16:1468-77. https://doi.org/10.1007/s00330-005-0133-x. 
[17] Afshar-Oromieh A, Babich JW, Kratochwil C, Giesel FL, Eisenhut M, Kopka K, et al. The Rise of PSMA Ligands for Diagnosis and Therapy of Prostate Cancer. J Nucl Med 2016;57:79S-89S.

https://doi.org/10.2967/jnumed.115.170720.

[18] Bravaccini S, Puccetti M, Bocchini M, Ravaioli S, Celli M, Scarpi E, et al. PSMA expression: a potential ally for the pathologist in prostate cancer diagnosis. Sci Rep 2018;8:4254.

https://doi.org/10.1038/s41598-018-22594-1.

[19] Park SY, Kim CK, Park BK, Lee HM, Lee KS. Prediction of biochemical recurrence following radical prostatectomy in men with prostate cancer by diffusion-weighted magnetic resonance imaging: initial results. Eur Radiol 2011;21:1111-8. https://doi.org/10.1007/s00330-010-1999-9.

[20] Sokmen BK, Sokmen D, Ucar N, Ozkurt H, Simsek A. The correlation between biological activity and diffusionweighted MR imaging and ADC value in cases with prostate cancer. Arch Ital Urol Androl 2017;89:277-81. https://doi.org/10.4081/aiua.2017.4.277.

[21] Jena A, Taneja R, Taneja S, Singh A, Kumar V, Agarwal A, et al. Improving diagnosis of primary prostate cancer with combined 68Ga-Prostate-Specific Membrane Antigen-HBEDCC simultaneous PET and multiparametric MRI and clinical parameters. AJR Am J Roentgenol 2018;211:1246-53. https://doi.org/10.2214/AJR.18.19585.

[22] Wetter A, Lipponer C, Nensa F, Heusch P, Rübben H, Schlosser TW, et al. Quantitative evaluation of bone metastases from prostate cancer with simultaneous [18F] choline PET/MRI: combined SUV and ADC analysis. Ann Nucl Med 2014;28:405-10. https://doi.org/10.1007/s12149-014-0825-x.

[23] Wang L, Yu F, Yang L, Zang S, Xue H, Yin X, et al. 68Ga-PSMA-11 PET/CT combining ADC value of MRI in the diagnosis of naive prostate cancer: Perspective of radiologist. Medicine (Baltimore) 2020;99:e20755. https://doi.org/10.1097/MD.0000000000020755.

[24] Wu X, Reinikainen P, Vanhanen A, Kapanen M, Vierikko T, Ryymin P, et al. Correlation between apparent diffusion coefficient value on diffusion-weighted MR imaging and Gleason score in prostate cancer. Diagn Interv Imaging 2017;98:63-71.

https://doi.org/10.1016/j.diii.2016.08.009. 